\title{
Part 1: The Wind Tunnel Model Design and Fabrication of Cal Poly's AMELIA 10 Foot Span Hybrid Wing-Body Low Noise CESTOL Aircraft
}

\author{
Kristina K. Jameson', David D. Marshat: ${ }^{2}$, Rory Goiden ${ }^{3}$, and Eric Paciano* \\ California Polyfechnic State University, San Lais Obispo, CA, 93407 \\ Rober J. Englar and Richard J. Gacta ${ }^{5}$ \\ Georgia Tech Research Institute, Atlanto, GA 30332-0844 \\ and \\ Juy Pyterson ${ }^{\top}$ and Dave Mason \\ Patersomiabs, Inc., Kent, WA 9803 I
}

\begin{abstract}
A collaboration between California Polytechnic Corporatlon with Georgla Tech Research Instltute (GTRJ) and DHC Engineering worked on NASA NRA to develop predlctlve capabilities for the design end performance of Cruise Eficient, Short Teke-Off and Landing (CESTOL) subsonic aircraft. In addition, a large seale wind tunnel effort to validate these predictive capabilities for this NRA for aerodynamic end ecoustic performance during tokeoff and landing hos been undertaken. The model, Advanced Model for Extreme Lift and Improved Aeroacoustles (AMELJA), was designed as a 100 passenger, N+2 generation, regional, crulse efjiclent short takeoff and lend (CESTOL) airliner with hybrid blended wing-body with circulation control and upper surbace blowing. The model design wos focused on JueJ-saylngs and notse gools set out by the NASA $N+Z$ deflnltlon. The AMEliA has $10 \mathrm{ft}$ wing apan. PatersonLabs was chosen to bulld AMELIA. The National Full-Scale Aerodynamic Complex (NFAC) 40 ft by $80 \mathrm{ft}$ wind tunnel was chosen to perform the large-scale wind tunnel test in the sumbier of $201 \mathrm{l}$.
\end{abstract}

\section{Introduction}

$\mathrm{W}$ ith the very recent advent of NASA's Environmentally Responsible Aviution Project (ERA)', dedicated to designing aircraft that will reduce the impact of aviation on the environment, there is a need for research and development of methodologies to minimize fuel buth, emission, and a reduction in community noise produced by regional airlines. ER.A is specifically concentrating in the aroas of aiframe technology, propulsion technology, and vehicle systems integration all in the time frame fur the aircraft to be at a Technology Readiness Level (TRL) of 4-6 by the year of 2020 (deemed $N+2$ ). The proceeding project looking into similar issues was led by NASA's Subsonic Fixed Wing Project and focused on conducting research to improve prediction methods and technologies that will

\footnotetext{
I Assistant Professor, Aerospace Engineeting, San Luis Obispo, Ca 93407, AIAA Member.

${ }^{2}$ Associate Professor, Aerospace Engineering, San Luis Obispo, Ca 93407, AlAA Member.

${ }^{3}$ Graduate Student, Aerospace Engineering, San l.uis Obispo, Ca 93407, AlAA Student Member.

${ }^{4}$ Undergraduate Student, Aerospace Engineering, San Luis Obispo, Ca 93407, AIAA Student Member.

${ }^{5}$ Pribcipal Research Engincer, Georgia Tech Research Institute, Atlante, GA 30332, AlAA Member.

${ }^{6}$ Research Engineer, Georgia Tech Research Institute, Atlanta, GA 30332, AIAA Member.

'President, patersonlobs, inc., Kent, WA 9803I, AIAA Member.

${ }^{8}$ Model Desigrer, patersonlabs, jnc., Kenc, WA 9803 I, AIAA Member.
} 
produce lower noise, lower emissions, and ligher performing subsonic aireraft for the Next Generation Air Transportation System.

The work provided in this insestigation was an NRA funded by Subsonic Fixed Wing Project starting in 2007 with a specific goal of conducting a large scale wind tunnel test along with the development of new and jmproved predictive codes for the advanced powered-tift concepts. These concepts are incorporated into the wind tunnel model and in conjunction with the verification of these codes by the experimental investigation an experimesical data base will be obtained during the wind tunnel lest. Powered-lift concepts investigated are Circulation Control (CC) wing in conjunction with over the wing mounted engines to entrain the exhaust to further increase the lift generated by $\mathrm{CC}$ technologies alore.

There are a number of papers in the past few years presenting computational studies of $C C$ technologies. Most of them have focus on 2D studies. ${ }^{2-11}$ While there are a number of excellent $2 \mathrm{D}$ experimental datasets available for such CFD validation ${ }^{12-15}$, the same is not true for 3D experimental data ${ }^{16}$. This effort aims to address this short fall by creating a comprehensive and relevant 3D database for current and future 3D simulations. Experimenta] measurements included in the database will be forces and moments, sutface pressure distributions, local skin friction, boundary and shear layer velocity profiles, far-field acoustic dala and noise signatures from turbofan propulsion simulators. This paper focuses on designing and developing a model wilh NASA's $\mathrm{N}+2$ goals for less environmental impact as well as the fabrication of a full span witnd unnel model to be used to create the $3 D$ validation database for numerical simulations. Specifically, the model was designed as a l00 passenger, regional. cruise efficient short takeoff and land (CESTOL) aitliter with hybrid blended wing-body with circulation cortrol. The configuration was developed by David Hall and refined by Cul Poly. The wind tumel model was sized by the NRA and the size of available wind tunnels, which scaled the model to a $10 \mathrm{ft}$ span. The resulting design is the Advanced Model for Extreme Lif and Improved Aeroacoustics (AMELIA) and is the subject of two companion papers. Parl I of this paper will describe the conceptual designts considered for this project, the selected configuration adapted for a wind tumnel model, the internal configuration of AMELIA, and the experimental measurements chosen in order to satisfy the requirement of obtaining an experimental measurement database. Part 2 of this paper (Preparation for Wind Tusnel Model Testing and Verification of Cal Poly's AMELIA 10 Foot Span Hybrid Wing-Body Low Noise CESTOL Aircraft) for a full description the progress of the large-scale wind tunnel test along with the experimental techniques that will be employed during the test. Plense see Refs. 19-24 for more details on the predicted petfommance of this CESTOL aircraft along with the improvements of the predictive codes.

\section{AMELlA Design Considerations}

NASA is committed to identifying solutions that meet improvement goals for noise, emissions, and energy usage (fuel burn). They have classified the $\mathrm{N}+2$ design metrics as a $40 \%$ reduction in fuel consumption, progress towards $-42 \mathrm{~dB}$ lower noise levels, a $70 \%$ decrease in emissions, and a $50 \%$ reduction in feld length performance over current generation aircrafts. Theoretically the aircraft should reach a Technology Readiness Level (TRL) of 4-6 by the year 2020. Dave Hall al DHC Engincering submilted conceptual designs of four separate configurations to address the $\mathrm{N}+2$ goals with a down selection by Cal Poly to one favorable configuration.

\section{A. Conceptual Designs Considered}

Four CESTOL configurations were developed for consideration for the large-scale wind tunnc] [est. The first Configuration I - has the most conventional appearance, in that it employs the tubc-and-wing layout. This configuration utilizes a high aspect ratio wing along with a cnciform tail. Utilizing over the wing mounled engines upper surface blowing is provided, which when combined with circulation control at the trailing edge, creates the powered lift recessary for short takeoff and landing. The inboard section of the wing was specifically designed to enhance flow turning ability during these flight segmenty. An isometric view of Configuration 1 is provided in Fig. 1 . 


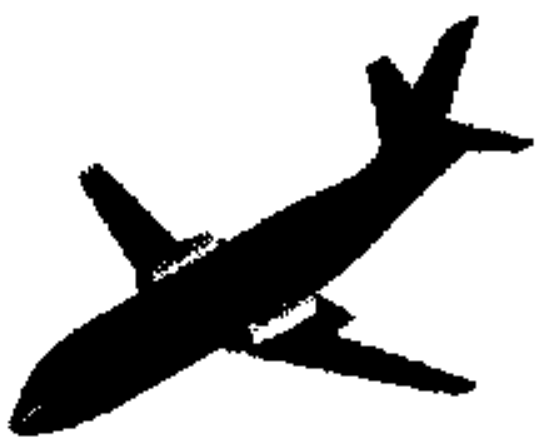

Figure 1. Configuration 1 is comprised of a high aspect ratio wing, over the wing engines, citculation control at the trailing edge and a cructform tail.

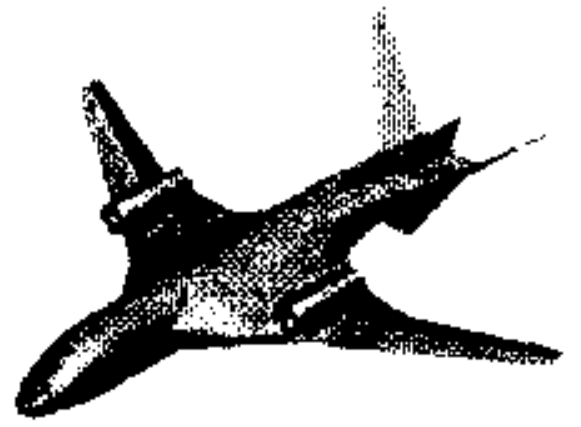

Flgure 2. Conflguration 2 utilizes a bybrid blended wing body, over the wing mounted engines, V-toil and elrculation controt at the leading ind traillng edge of the wings.

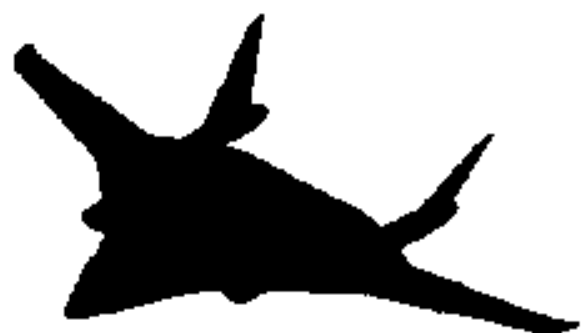

Figure 3. Configuration 3 is a complete blended wing body with embeddert engines. chartnel wittlg.
Drastically different from the first, the second contiguration ilizes a Hybrid blended-Wing-Body (HWB). Upper surface owing coupled with leading and trailing edge blowing for reulation control provides powrered lift system. The aft fuselage minates in a beaver tail, where a structural dorsal provides Iditional structural support. Configuration 2, shown in Fig 2, nploys a V tail in conjunction with aft fuselage strakes to aid in sw atlachment.

The third configuration was inspired by recent interest in an retaft utilizing a true Blended-Wing-Body (BWB). This aircraft theept is a significant departure from the first two aircraft designs that the two nurbofat engines are embedded within the very thick ing root; this can be seen in Fig. 3. The exhaust discharges through high aspect ratio 2-D nozzle at the trailing edge of the vehicle. The intent is not only to produce thrust through this nozzle throughout the flight but to create increased flow circulation around the aircraft gemerating additional lift during takeoff and landing.

The final and most complex design is shown in Fig. 4, termed the Diamond-Wing-Body (DWB). It may be thought of as a JoinedWing with a vertical structural member joining the fore and aft wings at the outer span points. The jutent is to improve local air fiow and mitigate shock fomation at bigh subsonic Mach numbers. These vertical metnbers are more like winglip yajls than winglets and ace structurally as struts. The forward wing sweeps afl, and the aft wing swieeps forward forming a diamond planform shape in the top view. Both wings have a high aspect ratio. The propulsion system is a medium-sized geared turbofan engine mounted within a

Afler close consideration of each design, it was apparent that Configuration I was too conventional to be considered an $\mathrm{N}+2$ design. Contiguration 4 , on the other hand, was too advanced to be considered within an $\mathrm{N}+2$ timeframe. A large seale wind tunnel test, being conducted by a competing NRA utilized a test model that was similar to Configuration 3 in that it was a blended wing body with circulation conlto ${ }^{18 .}$ Configuration 2 was considered to be at the appropriate level for the $\mathrm{N}+2$ time frame. Further investigations into this design elso showed that a 10' span model based on Configuration 2 would not exceed the load linits of all our perspective tesl locations. After consulting all involved in this project, it was decided that Configuration 2-the Hybrid blended-

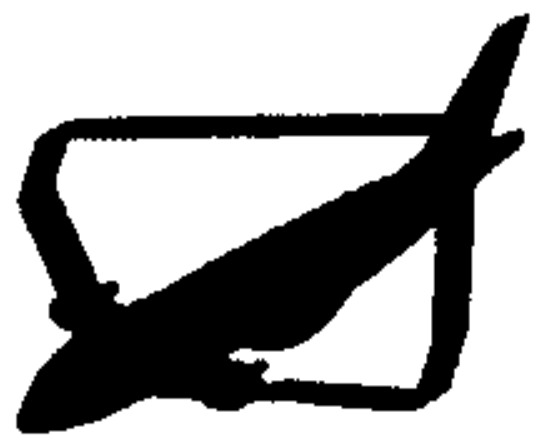

Figure 4. Conflguration 4 utilizes a high aspect ratio wing, in a dimmond wing configuration. 
Wing-Body—was best sujled for the AMELIA test. Figure 5 shows a rendering of Configuration 2 in flight after

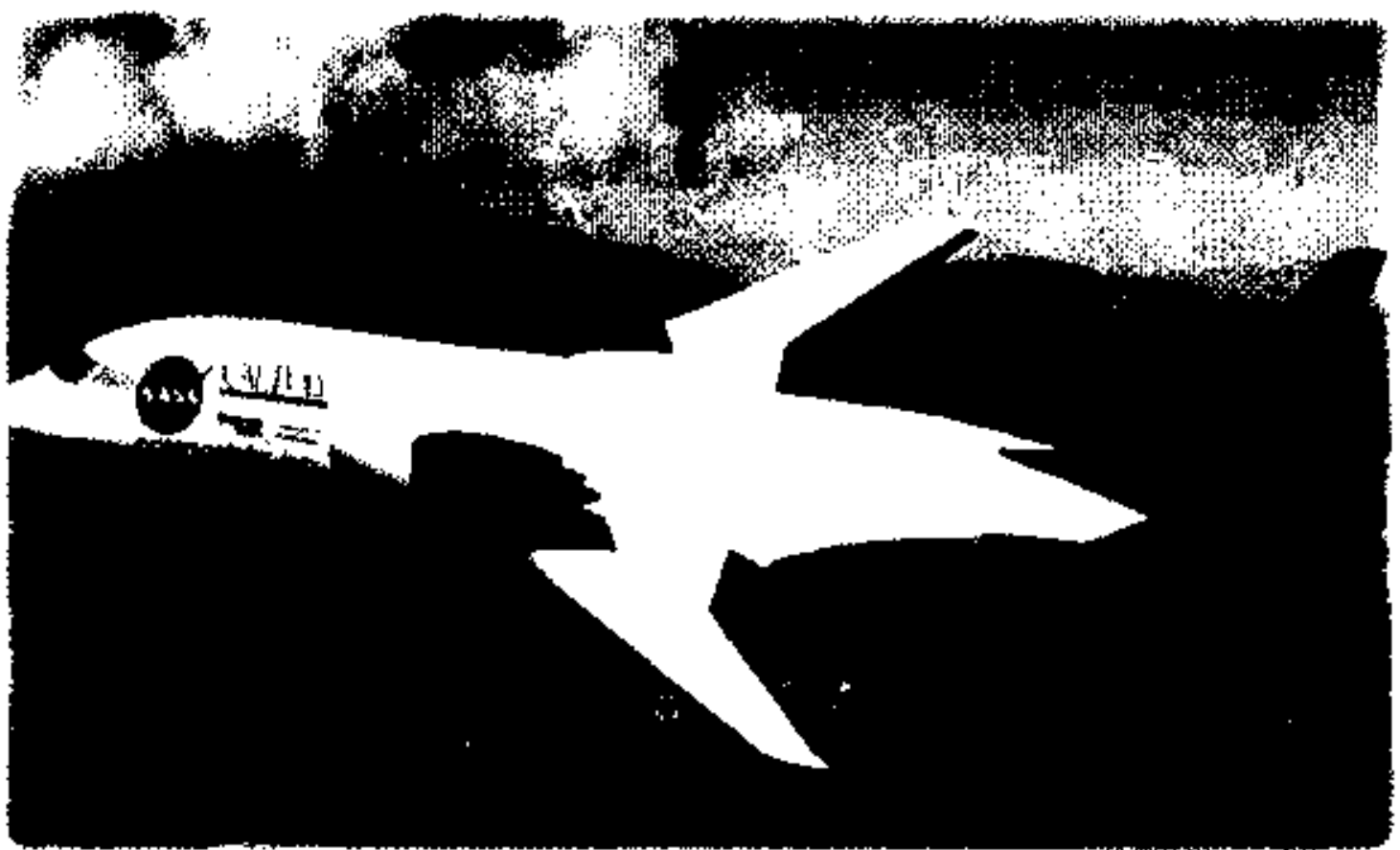

Figare S. The finat destgnn iteretion of Contigurntion 2; AMELlA's lull scale conceptual mortel in flight nove Howatt,

many design refinement iterations.

\section{B. AMELIA Design Features}

In order to utilize the Configuration 2 geomerty in a large-scalc wind tunnel test setting, many design modifications were needed. The most significant alteration to the geometry carne in the mounting system of the wind tunnel model. A sting was chosen as the ideal method to measure aerodynamic forces and moments, mainly for its ability to take measurements non-intrusively. Direct mounting of the modet to the sting through the aft end raised concerns with disturbing the flow around the beaver tail. An underbody mount was designed to provide an attachment location with minimal flow disturbance. The mount is [aited with a clamshet] blade that exterds vertically from the sting tip. The blade mount also serves to extend the negative angle of attach limit. Figure 6 shows a three view drawing of the model mounted to the blade attachment with empennage removed and relevant dimensions shown. The tail empennage is not shown in the three-view because it will not be atlached to the model during the majority of the testing. due to the fact that the main fucus of the testing is on seroacoustic and aerodynamic measurements of the power lift system. The strukes, structural rudder and V-tail as seen in Fig. 5 were manufactured in order to supplemenl subsequent research and testing. These surfaces attach to the model via ofl blocks.

The selected configuration utilizes an optimized supercriticyl airfoil ${ }^{19,20}$ with a dual radius flap at the trailing edge ${ }^{21}$. In order to mituimize cost and complexity of the model, dual radius flaps of $0^{\circ}, 30^{\circ}, 60^{\circ}$ and $90^{\circ}$ deflections were proposed to be manutactufed, as opposed to a mechanical flap where the deflection angle can be varied. The $90^{\circ}$ flap deflection was later changed to $80^{\circ}$ due to issues with the manuracturing of the flap with the appropriate blowing slot height. The flaps of the Configuration 2 design were also modified to be a single continuous flap for cach wing, in order to reduce the amount of flow disturbance from discontinuilies of the flap surface as wetl as allowing for less complicated configuration changes while the model is mounted on the sting. A cut away view of the model, with the $0^{\circ}$ and $80^{\circ}$ flap, is shown in Fig. 7. Figure 7 also highlights many of AMELIA's unique features, such as the internal flow control systems, the balance block, and the support structure for the over the wing mounted engines. 

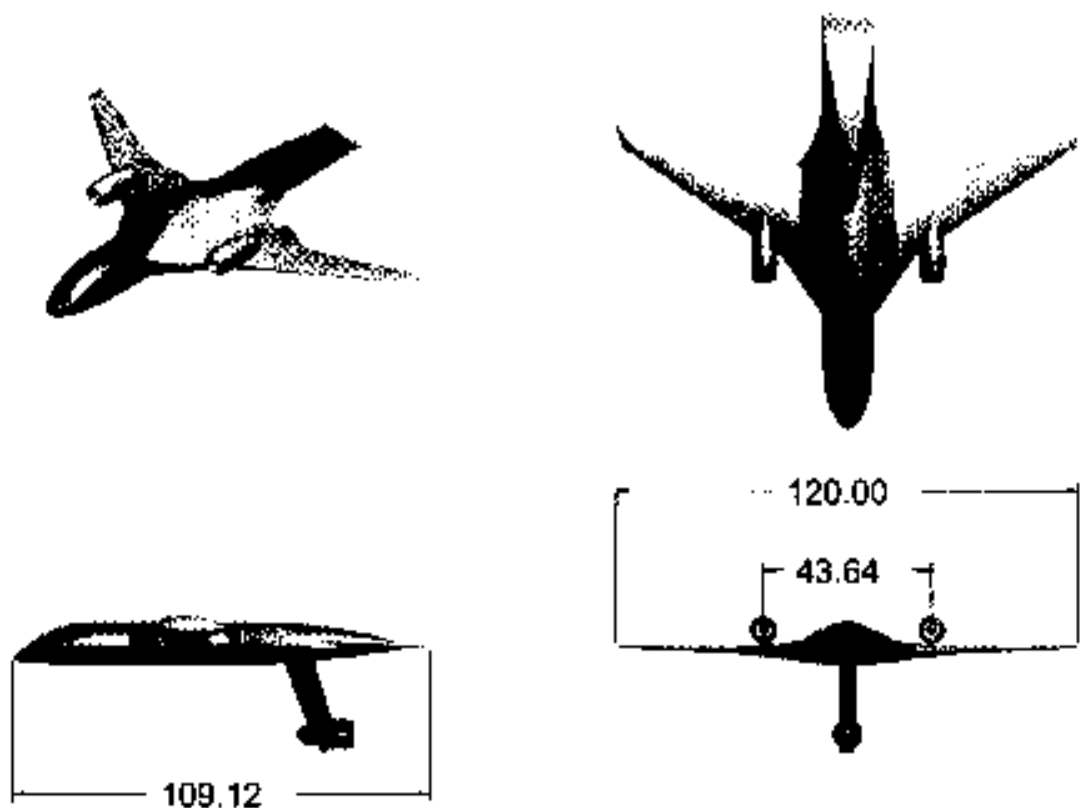

"Note: All Dlmensions In Inches

Figure 6. A threc-view drawlng of AMELIA with sting-blade athachment and tail surfaces removed.

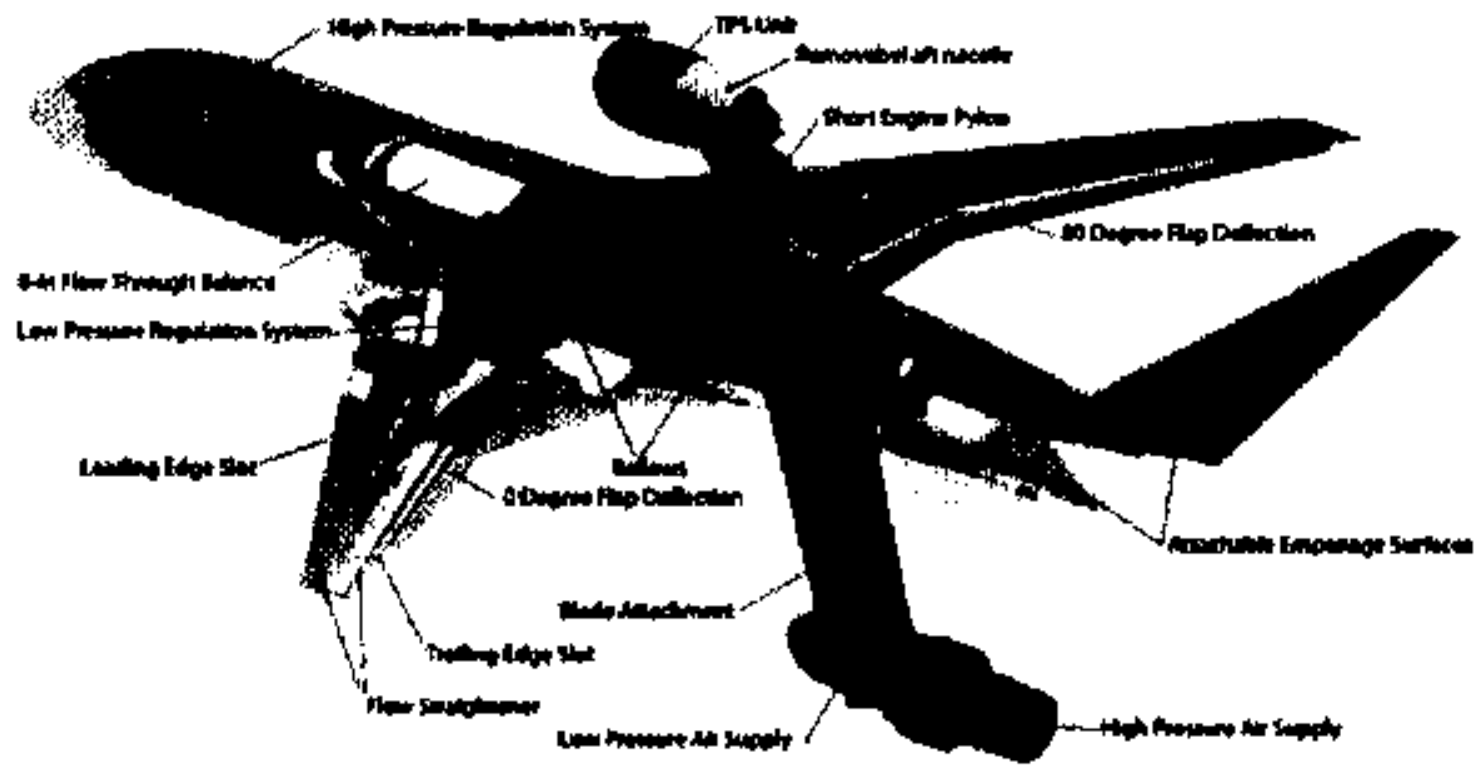

Figure 7. A section view of AMELIA, revealing the complex futcrnal components highlighting the flow system for the powered lift system and the flow-though balance.

C. High and Low Pressure Alr Systems

Plumbing for preassureized-heated air enters the model though the sting-blade attachment supplying the necessary high and lower pressure ait for the powered lift system. The larger blue fixture shown at the bottom of the 
schematic in Fig. 7 is the entry point for the high-pressure air required to power the Turbine Propulsion Simulator (TPS) units. This system (600 psi meximum determined by the limits of the flow through balance provided by the Triumph Group) first travels through the NFAC provided sting into the fabricuted sting-blade altachment making two approximately 900 cums before entering the $8 "$ flow though balance. On the downstream side of the balance a separate now control plenum and system regulates the air flow to the lef and right TPS units. The airflow is adjusted using corical plugs that can be remotely controlled while the tunnel is in operation. The conical plugs are driven using MMP 24vde geamolors, and use linear potentiometers for position feedback. The plugs can be positioned to provide from $0-100 \%$ mass flow. The TPS unit tow is supplied through stajnless stexl pipes that attach to wing mounted pylons. Figure 8 a shows the complete piping and mass flow control plenum for the high pressure ait system along with the sting-blade attachment while 86 is a head on view of the downstream flow control system bighlighting the staggered plumping layout necessary to tout the pressurized line to each of the TPS unis.
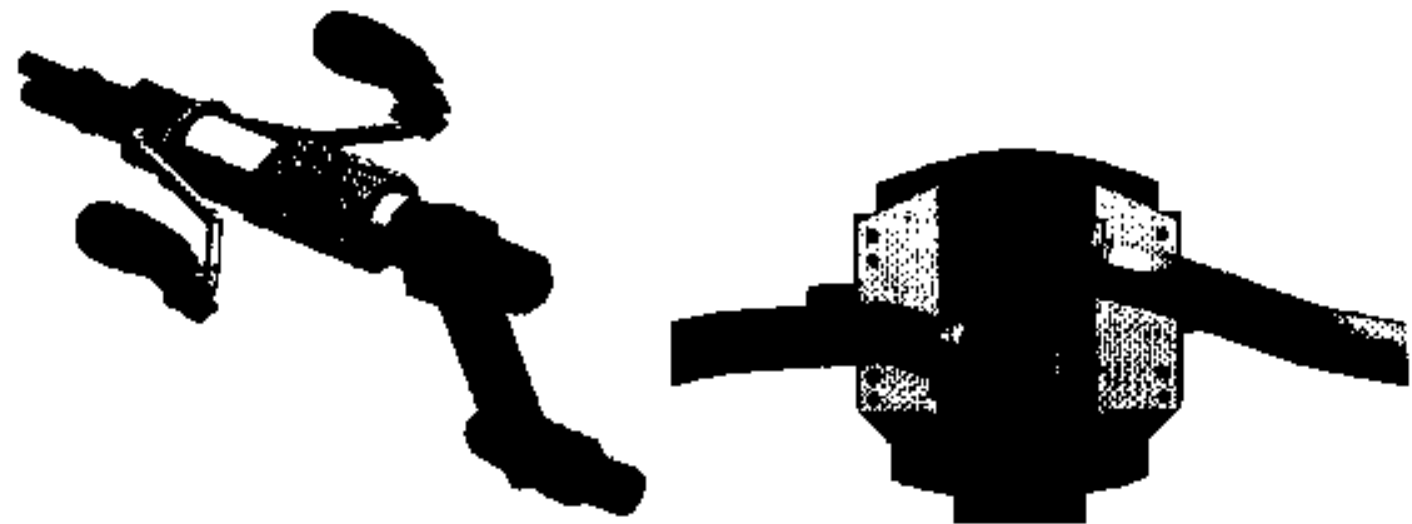

Figure 8. A schematic of the high pressure air system where (a) shows the complete systen from model entry to the TPS anits and (b) shaws a head on view of the downstream mass flow control system.

The low pressure system (approximately 100 psi) will be used to supply the air to the plenums that feed the slots at the leading and trialing edges for the circulation control wing. This system is fed via a pipe attached to the underside of the sting arm, which connects to the blade body. Air travels up the blade where it is split into the left and right wings allowing for the conversion of nos-metric to metric to be made though a two bellows systern. Once the flow becomes metric on each wing the air is dispersed into low pressure plenum, shout purple in Fig. 9a and $5 \mathrm{~b}$. Each low pressure plenum consists of four butterfly valves controlled via $24 \mathrm{wdc}$ gear motors, with rotary pots for feedback allowing each of the slot plenums separate flow control from $0-100 \%$. The flow to each slot plenums will be remotcly controlled allowing for quick respunse time during tunnel operation.
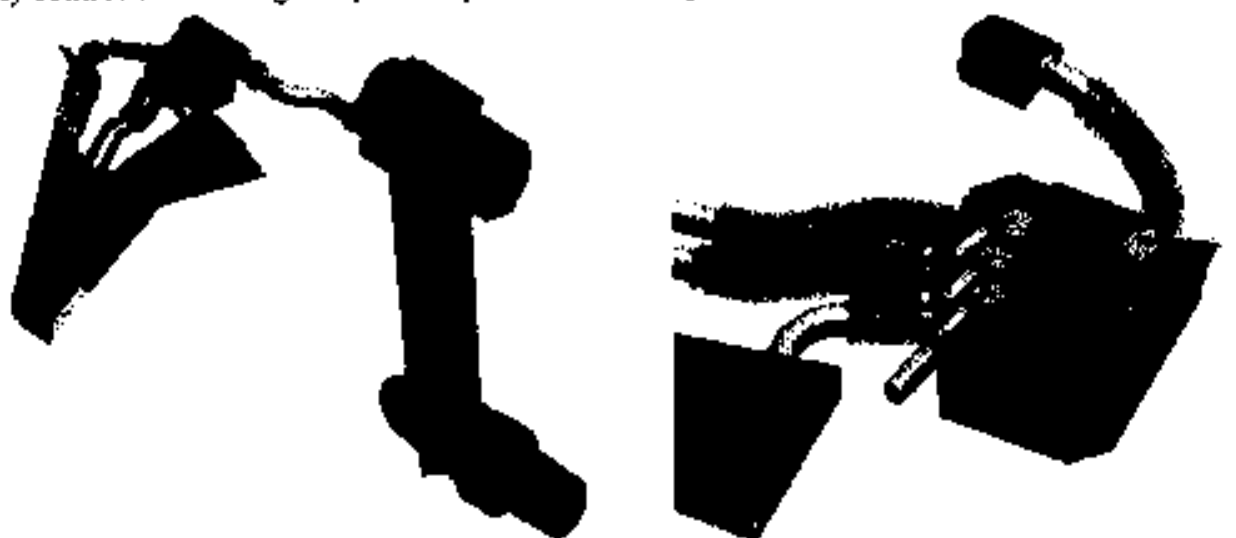

Fjgure 9. A schematic of the low pressere dir system where (a) shows the complete system for the left wing Including the plenums and plumping thought be sting blade attachment and (b) shows the structure for the Internal mass flow control system tor each of the four slot plenums In the left wing.

6

Americar Institute of Aeronautics and Astronautics 


\section{Turbine Propulsion Simulatars}

The turbine propulsion simulators were incorporated in the wind tunnel model as an atlempt to replicate the exhaust flow of a turbofan engine. One of the primary rescarch objects in this investigation is the ability to entrain engine exhaust from upper surface blowing with the flow from the circulation control wing. $\mathrm{As}$ a means to evaluate this entraimment ability, two separate engine heights will be investigated during testing. Hleight adjustmetts will be completed using faired structural pylons. ${ }^{2123}$ These pylons also act as pressure vessels within which the high pressure air is fed to the TPS units. Altering the model for engine height adjustments is projected to be the most time consuming modification and therefore will be kept to a minimum to decrease time in the tunnel.

The turtine propulsion simulators are TDI model 44I simulators on loan from NASA Langley. Internal to the

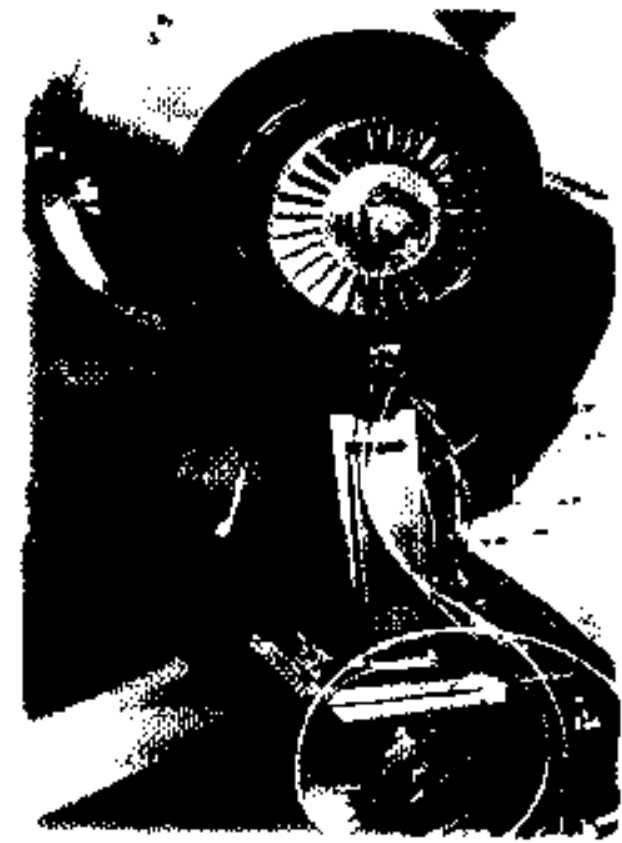

Figure 10. $A$ photograph af the Model 441 TPS unit installed in the nocelle mounted on AMELIA.
441 , compressed ait powers a thres stage turine, which drives the two stage far. The units are capable of producing $175 \mathrm{lbs}$ of thrust, at $6.5 \mathrm{lb} / \mathrm{s}$ total mass flow rate. The TPS units are heavily instrumented with thermocouples, total probes, and static ports, an acceleromeler, and a RPM pick-up in order to permit thorough hes]th monitoring during testing. In the case of a TPS unit failure, one back-up TPS unit has also been reconditioned and will be fitted with a nacelle and instrumentation. Additionally, the TPS will never be operated at its maximum operating condition; it is projected that the running the units at a derated value (approximately $80 \%$ ) will extend the life of each unit.

Cal Poly has obtained the rights to barrow a controller from NASA Ames compatible with the 441 TPS urits. The controller is LabVIEW based and witl be capable of operating two TPS units simultaneously. The controller should be functional be early 2011. A basic overview of the cuntroller wiring is given hete: the simulator bearing themocoupie leads, rpm leads, and acceleromeres leads for the two simulators is connected to an analog inpul card through to the front of the console. A oil thow sighal and an oil flow control line from a separate Jubrication cart is connected to the console. The console provides two output leads thal can be used to trigger shutdown of an external ais supply system if health limits are exceeded. During nominal operation, dedicated personal will set the air supply pressure as a function of $1 \mathrm{pm}$ and will remain in the loop while the TPS is in operation as the safety officer.

\section{E. Circulation Control Plenums}

Circulation control flow is delivered to the upper surface of the wing via eight separate plenums at the leading and trailing edges. Supplied by the low pressure system, each plenum has onc small cnirance which creates an uneven presșure distribution and vorticular flow. It order to reduce this complex flow, a thin partition of aluminum foum is used as a flow straightener and a means to achieve constant back pressure along the length of the plenum. Downstream of the aluminum form is a converging nozzle. The throat of the nuzzle varies in size (proportionally with the plenum) along the sparwise direction. Each slot plenum is instrumented with three pilot probes to measure the internal pressure to insure the plenum is at cotstent prossure during operation. Figure 11 shows a cross section of the leading and trailing edge plenums with the metal fuam placement for scale.

In the past circulation control experiments have had issues with accuralely predicting the flow has been precise knowledge of the slot height under ptessure. The height of the circulation control slot is an important factot jn the calculation of momentum coefficient, which is used widely in circulation control analysis. Values for slot height are typically known to sufficient fidelity post manufacturing, however under pressure slot height can vary by a large factor. Successful application of a capacitance based slot height measurement device at NASA Glean. lead us to beliovo that this technique may work well for the AMELIA model as well. The device is called the Capacitec GAPMAN, and utilizes a flexible wand, which can be taped to the lower surface of the slotupper sutface of the flap so that measurements can be made during testing. The calibration will include a thorough itvestigation of the use of 
aluminum foam to provide flow straightening and uniform pressure. Each plenum will be calibrated and pressurized separately. With the model arriving at Cal Poly in the next month, one of the top priorities will be calibration of the slot flow.
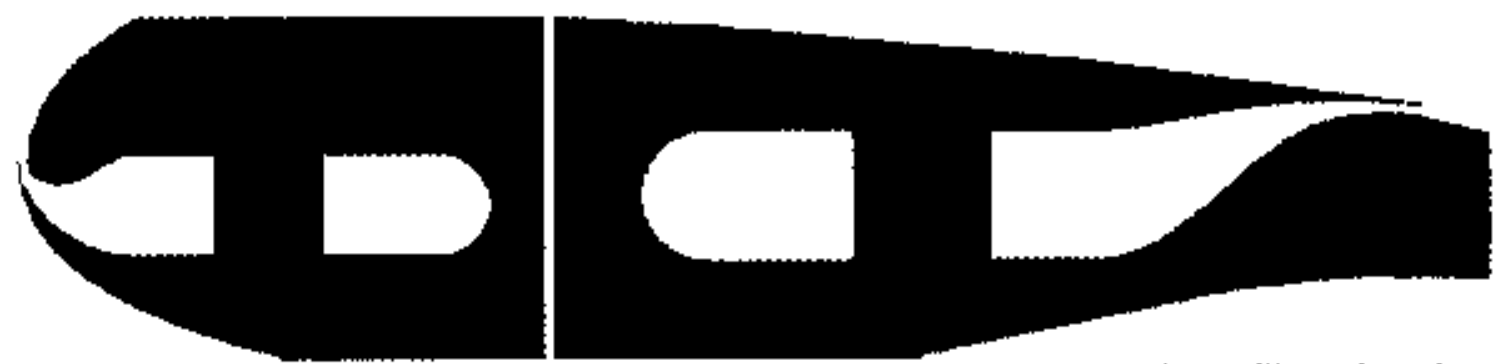

Figure 11. A schematic showing the crass section of $(\mathrm{a})$ the leading and (b) the trailing extge plenums highlighting the meal foam flow straighter plecement.

\section{F. Flow-Tbrough Balance}

The MC-130-8.00-Ai air balance will be utilized for the large scule wind tunnel test. The balance is being provided and calibrated by the Triumph Group. This particular balance is capable of operating with two separate fow systems at a maximum of $13 \mathrm{lb} / \mathrm{s}$ at $600 \mathrm{psi}$. AMELIA will be utilizing only one flow system for the high pressure portion of the powered lift system. Table I details the original maximum allowable louds fot the $\mathrm{MC}$ - $[30$ 8.00-Ai gir balance, where all expecied loads for AMELIA are within the allowable limits.

Table l, Original specifications for the MC-130-8.00-Ai air bnlance rated copncities (measured at the center of the belence)

\begin{tabular}{|c|c|c|c|c|c|}
\hline Normai & Pitching & Side & Yawing & Rolling & Axial \\
\hline Force (NF) & $\begin{array}{c}\text { Moment } \\
\text { (PM) }\end{array}$ & Force (SF) & $\begin{array}{c}\text { Moment } \\
\text { (YM) }\end{array}$ & $\begin{array}{c}\text { Moment } \\
\text { (RM) }\end{array}$ & Force (AF) \\
\hline Lbs & in-ibs & Lbs & in-lbs & in-lbs & Lbs \\
\hline 13,000 & 107,250 & 3,000 & 18,000 & 32,000 & 500 \\
\hline
\end{tabular}

\section{AMELIA Instrumentation}

The purpose of AMELIA is to provide both aeroacoustic and acrodynamic measurements to be used for current and future modeling vulidation efforts. Therefore it's imperative that the model be highly instrumetted in order to capture the maximum amuunt of flow physics possible for our given budget and timclinc. Almost all instrumentation ptacement occurs on the left wing and was chosen based on preliminary CFD results. Figure $I 2$ is a half-span schematic of the model illustrating the relative placement of the static pressure ports and unsteady pressure transducers. The model is instrumented with 230 static pressure ports in five chordwise groups and one spanwise group (highlighted in red in Fig. 12). The five chodewise localions were chose in order to investigate flow over the wing starting from the most jnboard sections as follows: Buttline (BL) 18 capnires the interactions between the Fuselage and wing, BL 240 investigates the flow downstram of the engine exit plane, BL 500 sheuld capture the flow over the wing with the least amount of inboard or outboard effects, and BL 638 and 642 are positioned close to one another for a direct comparison of pressure distribution on the outboard section of the wing with and without ejreulation control. The 8 unsteady pressure transducers were placed such that the cabit noise and the wing interaction downstream of the engine exit plane can be studiod.

Five static pressure ports are located on the right wing in order to verify symmetry in the pressure distribution. The right half of the model was intentionally left as uninstnumented as possible to allow for global skin friction measurements using FISF, for more information about this technique for AMELIA please refer to Part 2: Preparation for Wind Tumel Model Testing and Verification of Cal Poly's AMELIA IO Foot Span Hybrid WingBody Low Noise CESTOL Aircraft). 


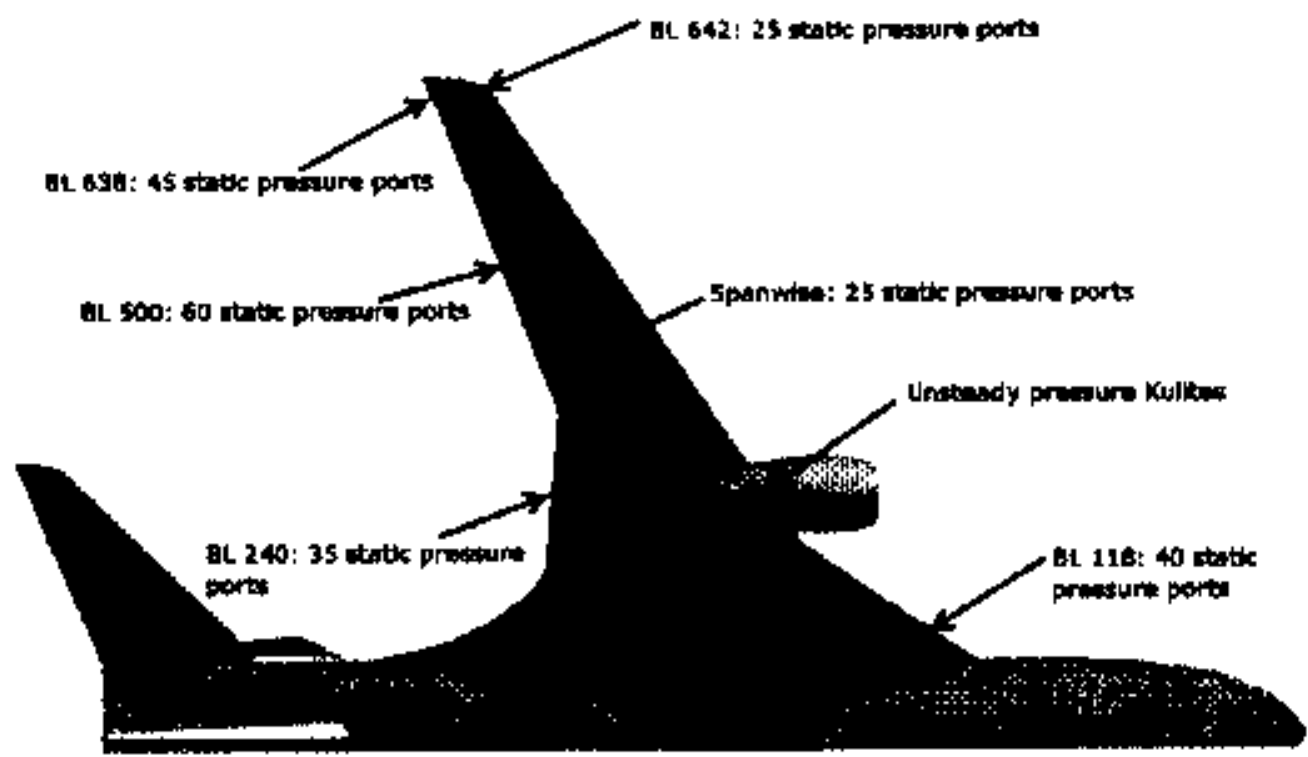

Figure 12, A schematic showing all external locations of the atatic pressurc ports and the unsteady pressure tranaducers.

\section{AMELIA Fobrication}

Patersonlabs, Irc. competed and won the contact to manutacture the $10 \mathrm{ft}$ span model. Fabrication of the model stated in the second year of the project and it is projected that the model will be completed by the end of January of 2011. Cumently Patersonlabs, Inc. has completed machining al] Elements of the model, including all outes mold lines, the high and low pressure air system, all internal plumbing had been routed, all static presșure taps and unsteady pressure ports have been installed, all flaps have been instrumented, and with the nacelles for the TPS. Figure 13 shows photographs of AMELIA before and after the paint without the nacelles justalled. Figure I4 shows the low and high pressure air control systems, respectively. Curently, AMELIA is undergoing hydrostatic proof testing, awaiting completion it will receive one more coat of paint, and the final stress analysis will be delivered to Cal Poly also by the end of January. Cal Poly has been receiving regular progress reports from Patersonlabs, Inc and is in constant communication regarding manufacturing process and needs.
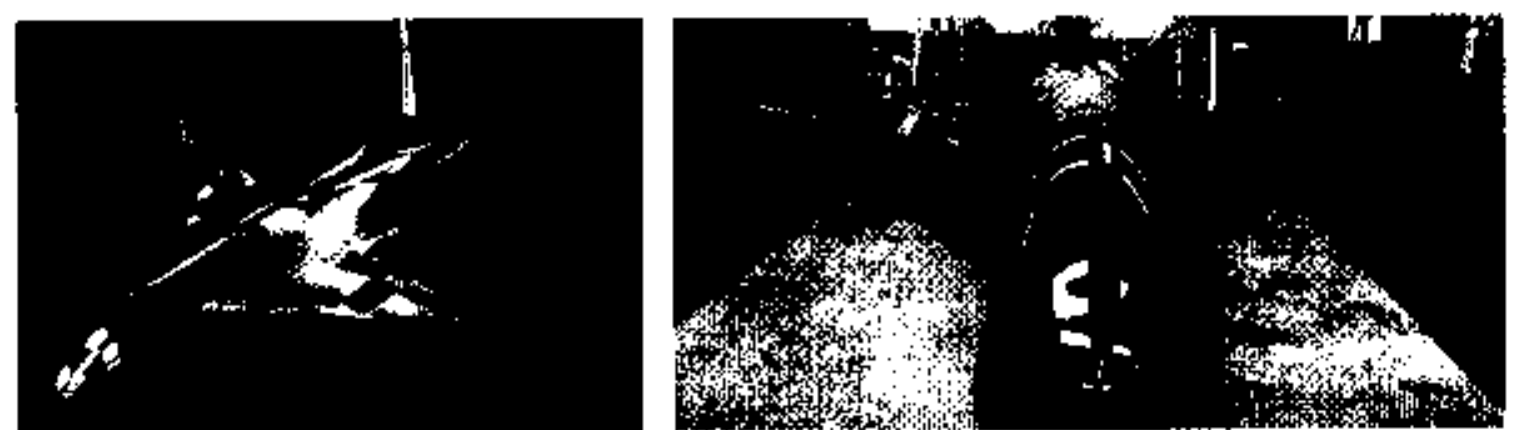

Figure I3. Photographs AMELIA (a) before paint with out the TPS nacelles installed and (b) paintexd in its flnal conflguration without the TPS nacelles installed. 

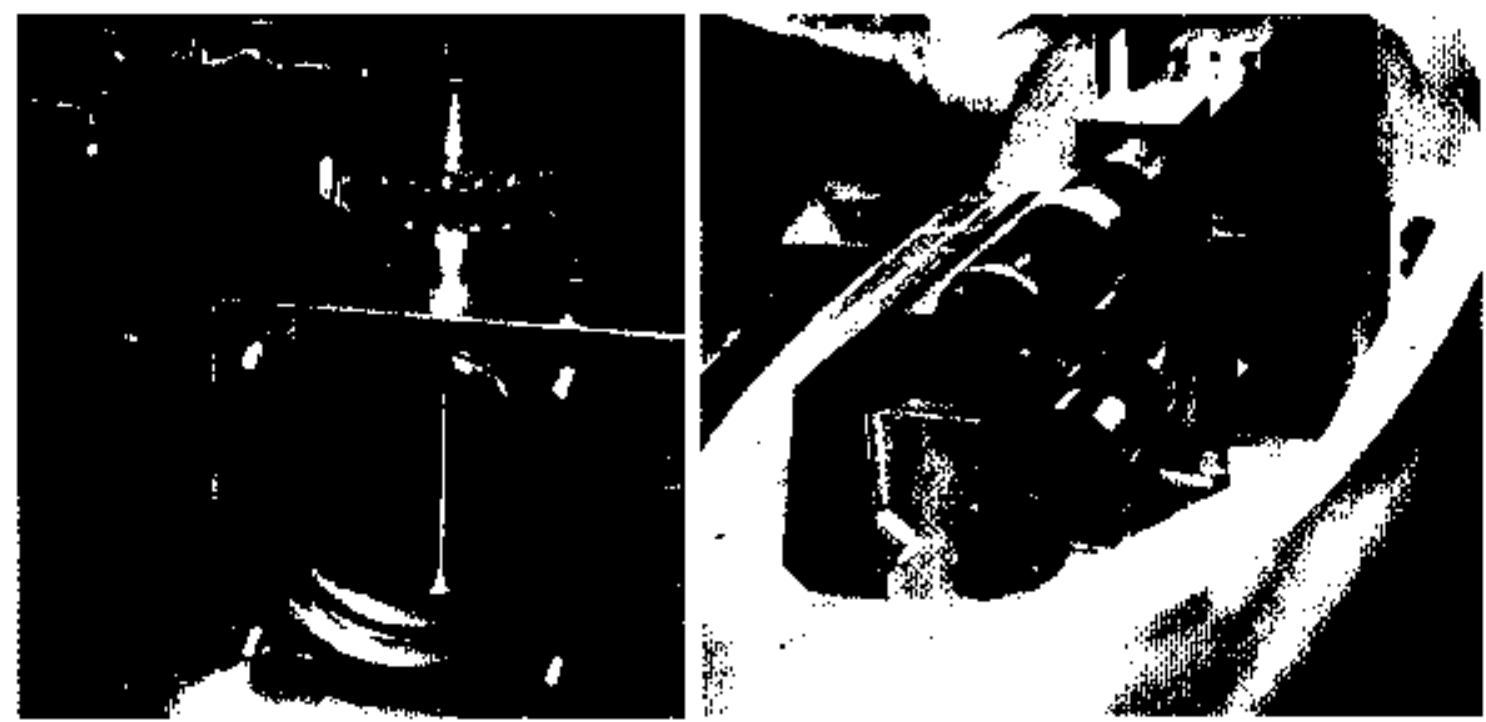

Figure 14. Phntagraphs of internal powered lift system (a) the low pressurc butterfy valve for leading edge slof plenum control and (b) the high pressore mass now control system for the left and right TPS units.

\section{Acknoldgements}

This work was funded as part of a NASA Research Arnouncement award under Cuntract \#NNLOAA5SC with Craig Hange and Clif Home as the tedhnical monitors. The authors wish to thank all of the students whe have participated in this work so far; their hard work and dedication have been invaluable to this research.

\section{References}

'Collier F. Overview of NASA's environmentally tesponsible aviation_ERA_ aroject. 2009 Fundamentuk Aeronautics Conference, Alanta GA, oral presentation, 2009.

${ }^{2}$ Madugundi D, Nagib H and Kiedaisch J. Evaluation of turbulence models through prediction of separated flows with and without flow control and circulation effects. 46th ALAA Aerospace Sciences Meeting and Exhibit, AlAA, Reno NV, AIAA-2008-0567, 2008.

${ }^{3}$ McGowan $G$ and Gopalarathnam A. Computational study of circulation control airfoil using FLUENT. Applications of Circulation Controf Technology, edited by R. D. Joslin and G. S. Jones, Vol. 214 of Progress in Astronautics and Atronautics, chap. 21, Americar Institute of Aeronautics and Astronaulics, Inc., pp. 539-554, 2006.

${ }^{4}$ McGowan $G$, Gopalarathnam $A_{1}$ Xiao X, and Hassan H A. Role of turbulence modeling in flow prediction of circulation control airfoils. Applications of Circulation Confrol Technology, edited by R. D. Joslin and G. S. Jones, Vol. 214 of Progress in Astronautics and Acronatrics, chap. 19, Ameticant Institute of Aeronautics and Astronautics, Inc., pp. 499-510, 2006.

${ }^{5}$ Liu, Y., Sankar, L. N., Englar, R. J., Ahuje, K. K., and Gaeth, R, J. Computational evaluation of steudy and palsed set effects on a circulation control airfoil. Applications of Circtiation Control Technology, odiled by R. D. Joslin and G. S. Jones, Vol. 214 of Progress in Astronautics and Aeronautics, chap. 22, American Institute of Aeronautics and Astronautics, Inc., pp. 557-577, 2006.

${ }^{6}$ Chang III P A, Slomskj J, Marino,T, Ebert M P, and Abramson J. Full Reynolds-stress modeling of circulation control aitfoil. Applications of Circulation Control Technology, edited by R. D. Joslit and G. S. Jones, Val. 214 of Progress in Astronautics and Aeronautics, chap. 17, American Institule of Aeronautics and Astronautics, Irc., Pp. 445-466, 2006. 
${ }^{7}$ Paterson E G and Baker W J. RANS and detached-eddy simulation of the NCCR airfoil. Applications of Circulation Control Technolog;, cdited by R. D. Joslin and G. S. Jones, Vol. 214 of Progress in Astronatics and Aeronautics, chap. 16, American Institule of Aerenautics and Astronautics, Inc., pp. 421-444, 2006.

${ }^{8}$ Baker W J and Paterson E G. Simulation of steady circulation contrul for the general aviation circulation centrol (GACC) Wing. Applications of Circtiation Control Technology, edited by R. D. Joslin and G. S. Jones, Vol. 214 of Progress in Astronatics and Aeroneutics, chap. 20, Ametican Institute of Aerunallics and Astronautics, Inc., pp. $513-537,2006$.

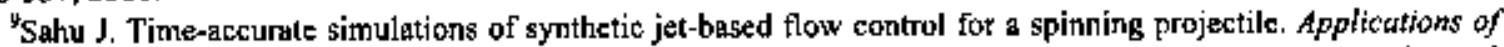
Circutation Control Technology, edited by R. D. Joslin and G. S. Jores, Vol. 214 of Progress in Astronautics and Aeronautics, chap. 23. American Institute of Aeronautics and Aslronautics, Inc., Pp. 579-596, 2006.

${ }^{10}$ Zha G C and Paxton C D. Novel fiow control method for airfoil performance enhancement using co-flow jet. Appldcations of Circulation Control Technolozy, edited by R. D. Joslin and G. S. Jones, Vol. 214 of Progress in Astronautics and Aeronautics, chap. 10, American Institute of Aeronautics and Astronatics, Inc., pp. 293-3IA. 2006 .

"McGowan G, Rumsey C. L, Swanson R C, and Hassan H A. A three-dimensional computational study of a circulation control wing. 3rd AIAA Flow Control Conference, AlAA, San Francisco CA, AlAA-2006-3677, 2006.

${ }^{12}$ Owen F K. Measurement and analysis of circulation control tirtoils. Applications of Circwlation Control Technology, cdited by R. D. Joslin and G. S. Jones, Vol. 214 of Progress in Astronautics and Aeronautics, chap. 4 , American Institute of Aeronautics and Astronautics, Inc., pp. I0S-I12, 2006.

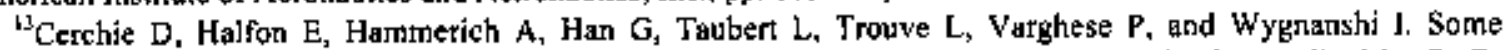
circulation and separation control experiments. Applications of Circulation Consrol Technology, edited by R. D. joslin and G. S. Jones, Vol. 214 of Progress in Astronauticy and Aeronautics, chap. 5, American Institute of Acronautics and Astronautics, lnc., pp. 113-166, 2006.

${ }^{14}$ Munro S E, Ahuje K K, and Englar R J. Noise teduction through circulation corlrol. Applications of Circtiation Control Technology, edited by R. D. Joslin and G. S. Jones, Vol. 214 of Progress in Astronautics and Aerongutics, chsp. 6, American Institute of Aeronautics and Astronautics, Inc., pp. 167-190, 2006.

${ }_{19}^{19} J$ ones G S. Pneumatic Flap Performance for a two-dimensional circulation control airfoil. Applications of Circulation Controf Technology, edited by R. D. Joslin and G. S. Jones, Vol. 214 of Progress in Astronautics and Aeronautics, chap. 7, American Instinute of Aeronautics and Astronautics, Inc., pp. I9I-244, 2006.

${ }_{16}^{16}$ Englar $\mathrm{R}$ J. Experimental Development and evaluation of pneumatic powered-lift super-STOL aireraft. Applications of Circulation Control Technology, edited by R. D. Joslin and G. S. Jones, Vol. 214 of Progress in Astronautics and Aeronautics, chap. 7, American Institule of Aeronautics and Astroneutics, Inc., pp. 191-244, 2006.

${ }^{17}$ Warwick G. Boejog works wilh eirlines on commercial blended wing body frejobter. Flight Intemational, 2007 ,

${ }^{1}$ Collies F, Zavaly E, and Huff D. Fundamental aeronautics program, subsonic fixed wing reference guide. NASA.

"Marshall, D., and Jameson, K., "Overview of Recent Circulation Control Modeling Activities at Cal Foly", AIAA-2010-348, AIAA 48 $8^{\text {th }}$ Aerospace Sciences Meeting and Exhibit, Orlendo, Fla.

${ }^{20}$ Lane $K$ A and Marshall D D. A surface patameterization method for airfoil optimization and high lift $2 D$ geotmetries utilizing the CST methodology. 47th AIAA Aerospace Sciences Meeting and Exhibit, AIAA, Orlando FL, AIAA-2009-1461, 2009.

${ }^{2}$ Lane K A and Marshall D D. Inverse airfoil design utilizing CST parameterization. 48th AIAA Aerospace Sciences Meeting and Exhibit, AlAA, Orlando FL, AIAA-2010-1228, 2010.

${ }^{27}$ Golden $\mathrm{R}$ and Marshall D D. Design and performance of circulation control flap systems," 48th AJAA Aerospace Sciences Meeting and Exhibit, AIAA, Orlando FL, AJAA 2010-1053, 2010.

${ }^{23}$ Englar R J, Gaeta R J, Lee W J and Leone V. Development of pneumatic over-the-wing powered-]ift technology; part I: acrodynamic propulsive. $27 \mathrm{th}$ AIAA Applied Aerodynamics Conference, AIAA, San Antorio TX, AlAA-2009-3942, 2009.

${ }^{24}$ Gaeta R J, Englar R J and Avera M. Development of pneumatic over-the-wing powered lift technology art II: aeruacoustics, 27th AIAA Applied Aerodynamics Conference, AlAA, San Antonio IX, AIAA-2009-3941, 2009. 